\title{
Pengaruh Kecerdasan Emosional terhadap Hasil Belajar Geografi Siswa SMA
}

\author{
Nurul Miftakhul Jannah ${ }^{1}$, Dwiyono Hari Utomo ${ }^{1}$, Budi Handoyo ${ }^{1}$ \\ ${ }^{1}$ Pendidikan Geografi-Universitas Negeri Malang
}

\section{INFO ARTIKEL}

\section{Riwayat Artikel:}

Diterima: 05-07-2019

Disetujui: $17-12-2019$

\section{Kata kunci:}

emotional intelligence; geography learning outcomes; high school student; kecerdasan emosinal; hasil belajar geografi; siswa SMA

\author{
Alamat Korespondensi: \\ Nurul Miftakhul Jannah \\ Pendidikan Geografi \\ Universitas Negeri Malang \\ Jalan Semarang 5 Malang \\ E-mail: nurulmiftakhuljannah@um.ac.id
}

\begin{abstract}
ABSTRAK
Abstract: This study aim is to determine the effect of emotional intelligence on geography learning outcomes. This study design was survey design. This study was divided into four stages those were the preparation stage, the implementation phase, the data processing stage, and the reporting stage. The subjects in this study was students from XII IPS I, XII IPS II, XII IPS III, XII IPS IV and XII IPS V. The data was collected in form of quantitative. There was two kinds of data that presented in this study, data obtained from teachers (personal documents), and data obtained from questionnaires. The results of the $t$ test analysis are smaller than the 0.05 significance level. Therefore it can be concluded that there is a significant effect between emotional intelligence and the learning outcomes of geography. Emotional intelligence has an effect on learning outcomes of $35.7 \%$ and the remaining $64.3 \%$ is not examined by researchers since those come from another variable. The researcher expects that further research can combine or find other variables that can influence the learning outcomes of geography.
\end{abstract}

\begin{abstract}
Abstrak: Penelitian ini bertujuan untuk mengetahui pengaruh kecerdasan emosinal terhadap hasil belajar geografi. Rancangan penelitian ini adalah penelitian survei yang dilakukan pada siswa. Tahapan penelitian dibagi menjadi empat, yaitu tahap persiapan, tahap pelaksanaan, tahap pengolahan data, dan tahap pelaporan. Subjek dalam penelitian yaitu kelas XII IPS I, XII IPS II, XII IPS III, XII IPS IV dan XII IPS V. Data yang dikumpulkan merupakan data kuantitatif yang diambil dari penyebaran angket. Data terdiri dari dua jenis yaitu data yang diperoleh dari guru (dokumen pribadi), dan data yang diperoleh dari penyebaran angket. Hasil analisis uji t lebih kecil dari taraf signifikansi 0,05. Dengan demikian, dapat disimpulkan bahwa terdapat pengaruh yang signifikan antara kecerdasan emosional dengan hasil belajar geografi siswa. Kecerdasan emosional berpengaruh terhadap hasil belajar sebesar $35,7 \%$ dan sisanya $64,3 \%$ merupakan variabel lain yang tidak diteliti oleh peneliti. Diharapkan untuk penelitian selanjutnya dapat mengombinasikan atau menemukan variabel-variabel lain tersebut yang dapat memengaruhi hasil belajar Geografi.
\end{abstract}

Hasil belajar merupakan perubahan yang terjadi mencakup tiga aspek yaitu kognitif, afektif dan psikomotorik. hasil belajar kognitif dapat dijelaskan sebagai hasil belajar yang berpusat pada olah pikir (intelektual) dari yang sederhana sampai pada yang kompleks. Hasil belajar afektif dapat dijelaskan sebagai kemampuan peserta didik dalam memperhatikan, merespons dan menerima. Hasil belajar psikomotorik dapat dijelaskan sebagai kemampuan dalam meniru, memanipulasi serta menemukan ideide baru dalam pembelajaran. Hasil belajar merupakan hal yang sangat penting sebagai bentuk dari ketercapaian tujuan pembelajaran yang telah dilakukan (Hanafy, 2018). Hasil belajar Geografi merupakan hal yang penting. Hasil belajar Geografi merupakan bentuk dari ketercapaian tujuan pembelajaran yang telah dilakukan. Hasil belajar Geografi menunjukkan keberhasilan dalam proses pembelajaran yang berlangsung. Hasil belajar Geografi juga dapat menjadi ukuran dalam pengambilan keputusan untuk proses belajar selanjutnya.

Berdasarkan observasi awal peneliti pada tanggal 13 Desember 2018, hasil belajar Geografi di SMA Negeri I Kutorejo masih belum maksimal. Hal ini dibuktikan dengan nilai rata-rata beberapa kelas jurusan IPS masih di bawah 80 . Tinggi rendahnya hasil belajar dipengaruhi oleh beberapa faktor yaitu faktor intrinsik dan faktor ekstrinsik (Retnowati, Ayres, \& Sweller, 2017). Faktor intrinsik merupakan faktor yang berasal dari dalam diri siswa itu sendiri seperti kecerdasan intelektual, kecerdasan emosional dan motivasi, sedangkan faktor ekstrinsik merupakan faktor yang berasal dari luar diri siswa yaitu 
lingkungan keluarga, lingkungan masyarakat, dan lingkungan sekolah. Dalam hal ini yang menjadi pokok pembahasan adalah kecerdasan emosional yang merupakan faktor yang dapat memengaruhi hasil belajar siswa dari dalam diri (intrinsik) siswa. Kecerdasan emosional merupakan salah satu indikator dalam kesuksesan akademik siswa, dimana bagi siswa yang memiliki kecerdasan emosional tinggi maka dia akan cenderung aktif dan bekerja lebih baik di kelompoknya. Kecerdasan emosional berperan penting dalam hal kesuksesan belajar siswa (Howe \& Howe, 2016). Beberapa penelitian terdahulu menyebutkan terdapat korelasi antara kecerdasan emosional dengan hasil belajar siswa SMA (Bar-On, 2006).

Beberapa orang sering menganggap bahwa kecerdasan emosional tidaklah penting. Padahal secara garis besar, $80 \%$ keberhasilan siswa dalam belajar dipengaruhi oleh kecerdasan emosional (Lutfriansyah, 2016). Kecerdasan emosional adalah kemampuan diri seseorang untuk merasa. Menurut (Mayer \& Mayer, 2012) "popular definition of emotional intelligence refer to various things, including motivation, empathy, sosiability warmth, and optimism”. Beberapa definisi kecerdasan emosional biasanya mengacu pada beberapa hal termasuk didalamnya, yaitu motivasi, empati, kecekatan sosial, dan optimisme. Kecerdasan emosional menjadi dominan karena pada saat siswa memiliki kecerdasan emosional yang tinggi maka ia akan mampu (1) mengenali emosi diri, memahami suasana hatinya pada saat tertentu; (2) mengelola emosi, dapat mengontrol dan mengetahui apa yang harus dilakukan untuk menstabilkan suasana hatinya; (3) memotivasi diri, tekun, terus berusaha dan tidak cepat puas; (4) mengenali emosi orang lain dikenal juga sebagai empati; (5) membina hubungan baik dengan orang lain.

Beberapa pertanyaan dalam tes kecerdasan emosional berisi tentang gambaran tingkat kecerdasan seseorang. Menurut (Murti \& Srimulyani, 2013) menyatakan "the firs component of emotional intelligence is emotional self-awareness". Komponen yang paling utama dalam kecerdasan emosional adalah mengenali emosi diri.(Salovey \& Mayer, 1990) menyimpulkan "Emotions typically arise in response to an event, either internal or external, that has a positively or negatively valenced meaning for the individual. Emotions can be distinguished from the closely related concept of mood in that emotions are shorter and generally more intense".

\section{METODE}

Penelitian ini merupakan sebuah penelitian dengan menggunakan pendekatan kuantitatif dan teknik pengujiannya menggunakan uji-t. Dalam hal ini uji-t digunakan untuk mengetahui apakah ada pengaruh antara variabel bebas terhadap variabel terikat. Dimana dalam penelitian ini variabel bebasnya adalah kecerdasan emosional dan variabel terikatnya adalah hasil belajar. Subjek dalam penelitian ini yaitu siswa IPS 1, IPS II, IPS III, IPS IV, dan IPS V yang berjumlah 134 siswa. Instrumen yang digunakan dalam penelitian ini yaitu angket. Alternatif jawaban yang dibuat berturut-turut, yaitu sangat setuju, setuju, tidak setuju, dan sangat tidak setuju. Pengumpulan data dalam penelitian ini dibagi menjadi empat tahapan yaitu (1) tahap persiapan; (2) tahap pelaksanaan; (3) tahap pengolahan data; (4) tahap pelaporan. Data yang diperoleh dalam penelitian yaitu data kuantitatif, terbagi menjadi dua, yaitu data internal dan data yang diperoleh dengan menggunakan angket. Data internal merupakan data yang diperoleh dari guru mata pelajaran. Analisis data dilakukan dengan bantuan program SPSS 16, teknik analisis data yang digunakan yaitu analisis deskriptif dan uji-t. Analisis deskriptif digunakan untuk mengetahui tingkatan dari masing-masing variabel penelitian. Uji-t digunakan untuk melihat signifikansi atau tidaknya antara variabel bebas terhadap variabel terikat. Dikatakan signifikan apabila t > 0,05 maka dapat disimpulkan terdapat pengaruh antara kecerdasan emosional terhadap hasil belajar.

\section{HASIL}

Berdasarkan analisis yang telah dilakukan, didapatkan hasil bahwa variabel kecerdasan emosional masuk dalam kategori sedang. Sedangkan untuk variabel hasil belajar. Berdasarkan analisis yang telah dilakukan, didapatkan hasil bahwa variabel hasil belajar di SMA Negeri I Kutorejo masuk dalam kategori rendah yaitu sebesar 35,3\%. Sebelum dilakukan uji hipotesis terlebih dahulu dilakukakn uji normalitas dan linieritas. Uji normalitas dilakukan untuk mengetahui apakah data yang diperoleh berdistribusi normal atau tidak. Data yang baik adalah data yang berdistribusi normal. Berdasarkan uji KolmogorovSmirnov dapat diketahui bahwa data kecerdasan emosional maupun hasil belajar geografi siswa berdistribusi normal. Pedoman pengambilan keputusan uuntuk uji normalitas yaitu apabila nilai signifikansi $\geq 0,05$ maka dapat diartikan data terdistribusi normal, sedangkan apabila nilai signignifikansi $\leq 0,05$ maka data tersebut dapat diartikan memiliki distribusi tidak normal. Hasil uji normalitas berdasarkan tabel Kolmogorov-Smirnov menunjukkan nilai probabilitas sebesar 0,196. Nilai probalitias atau Asymp Sig (2-tailed) tersebut $\geq 0,05$, sehingga dapat diartikan data yang diolah berdistribusi normal. Hasil uji linieritas yang telah dilakukan menggunakan bantuan SPSS 16 dengan taraf signifikansi 0,05 diperoleh nilai signifikansi 0,000 pada hubungan antara variabel kecerdasan emosional dengan hasil belajar geografi di SMA Negeri I Kutorejo. Hasil tersebut menunjukan bahwa hubungan antara kecerdasan emosional dengan hasil belajar geografi di SMA Negeri I Kutorejo bersifat linier.

Setelah melakukan uji asumsi klasik yaitu uji prasyarat analisis kemudian dilakukan analisis deskriptif. Dalam hal ini analisis dilakukan untuk mengetahui interval dari masing-masing variabel yaitu kriteria sangat rendah, rendah, sedang, dan tinggi. Penentuan kriteria dilakukan menggunakan rumus. Berdasarkan analisis yang telah dilakukan diperoleh skor tertinggi adalah 224, sedangkan skor terendah yaitu 158 dan range 66. Setelah dilakukan perhitungan tersebut maka dapat diketahui bahwa kriteria sangat rendah $<174,2$; kriteria rendah $<190,8$; kriteria sedang <207,5: dan tinggi $\leq 224$. Lebih jelasnya dapat dilihat pada tabel 1 . 
Tabel 1. Distribusi Persentase Kategori dari Variabel Kecerdasan Emosional

\begin{tabular}{lccc}
\hline \multicolumn{1}{c}{ Kategori } & Interval Nilai & Frekuensi & Persentase (\%) \\
\hline Sangat Rendah & $157,7-174,2$ & 11 & $7,8 \%$ \\
Rendah & $174,3-190,8$ & 22 & $16,1 \%$ \\
Sedang & $190,9-207,4$ & 49 & $36,2 \%$ \\
Tinggi & $207,5-224$ & 52 & $39,9 \%$ \\
\hline \multicolumn{2}{c}{ Jumlah } & 134 & $100 \%$ \\
\hline
\end{tabular}

Tabel 1 distribusi persentase menjelaskan hasil dari masing-masing kriteria, yaitu kriteria sangat rendah sebesar 7,8\% dengan jumlah siswa sebanyak 11; kriteria rendah sebesar 16,1\% dengan jumlah siswa sebanyak 22; kriteria sedang sebesar $36,9 \%$ dengan jumlah siswa sebanyak 49; kriteria tinggi sebesar 39,9\% dengan jumlah siswa sebanyak 52, sedangkan untuk skor rata-rata keseluruhan (mean) yaitu 200,27. Dengan demikian, dapat diartikan bahwa kecerdasan emosional siswa di SMA Negeri I Kutorejo masuk dalam kategori sedang. Dalam tabel distribusi persentase kecerdasan emosional masuk dalam nilai interval 190,9-207,4. Sedangkan untuk penentuan kriteria variabel hasil belajar menggunakan rumus, diperoleh hasil kriteria sangat rendah $<591$; kriteria rendah $<614$; kriteria sedang $<637$; kriteria tinggi $\leq 660$. Keterangan lebih lanjut dapat dilihat pada tabel 2.

Tabel 2. Distribusi Persentase Kategori dari Variabel Lingkungan Keluarga

\begin{tabular}{lccc}
\hline \multicolumn{1}{c}{ Kategori } & Interval Nilai & Frekuensi & Persentase (\%) \\
\hline Sangat Rendah & $565-588$ & 19 & $13,6 \%$ \\
Rendah & $589-612$ & 48 & $35,3 \%$ \\
Sedang & $613-636$ & 51 & $39,5 \%$ \\
Tinggi & $637-660$ & 16 & $11,6 \%$ \\
\hline \multicolumn{2}{c}{ Jumlah } & 134 & $100 \%$ \\
\hline
\end{tabular}

Tabel 2 distribusi persentase menjelaskan hasil dari masing-masing kriteria pada variabel hasil belajar yaitu kriteria sangat rendah sebesar 13,6\% dengan jumlah siswa sebanyak 19; kriteria rendah sebesar 35,3\% dengan jumlah siswa sebanyak 48; kriteria sedang sebesar 39,5\% dengan jumlah siswa sebanyak 51; dan kriteria tinggi sebesar 11,6\% dengan jumlah siswa sebanyak 16. Skor rata-rata keseluruhan (mean) untuk variabel hasil belajar yaitu 613,61 dan masuk dalam kategori rendah dengan interval 591 - 614. Hal ini dapat diartikan bahwa variabel lingkungan keluarga masuk dalam kategori rendah. Dengan demikian, dapat disimpulkan bahwa hasil analisis yang telah dilakukan diperoleh kecerdasan emosional siswa di SMA Negeri I Kutorejo masuk dalam kategori sedang, sedangkan hasil belajar Geografi siswa di SMA Negeri I Kutorejo masuk dalam kategori rendah.

Selanjutnya, setelah dilakukan analisis deskriptif untuk mengetahui kriteria masing-masing variabel dilakukan analisis yang terakhir dengan tujuan untuk mengetahui ada atau tidaknya pengaruh dari kecerdasan emosional siswa terhadap hasil belajar Geografi di SMA Negeri I Kutorejo. Berdasarkan hasil analisis yang telah dilakukan menggunakan bantuan IBM SPSS 16 diperoleh nilai signifikansi sebesar 0,000. Hal tersebut berarti hasil analisis uji t lebih kecil dari taraf signifikansi 0,05 yang menyatakan $\mathrm{H}_{0}$ ditolak. Jadi, kesimpulannya adalah terdapat pengaruh antara kecerdasan emosional siswa dengan hasil belajar Geografi di SMA Negeri I Kutorejo. Nilai output SPSS dari $\mathrm{R}^{\mathbf{2}}$ (Rsquare) hasil analisis regresi yaitu sebesar 0,261. Hal tersebut menunjukkan bahwa sumbangan efektif dari kecerdasan emosional terhadap hasil belajar Geografi sebesar $26,1 \%$. Persentase untuk sumbangan efektif sebesar 73,9\% berasal dari variabel bebas lainnya yang ikut serta dalam memengaruhi hasil belajar. Namun, variabel-variabel tersebut tidak termasuk dalam penelitian ini.

\section{PEMBAHASAN}

Berdasarkan analisis yang telah dilakukan, didapatkan hasil bahwa variabel kecerdasan emosional masuk dalam kategori sedang. Pada pengukuran deskriptif terkait variabel kecerdasan emosional peneliti menggunakan instrumen (a) mampu mengenali emosi diri; (b) mengelola emosi; (c) memotivasi diri; (d) mengenali emosi orang lain; (e) membina hubungan baik dengan orang lain. Berdasarkan keseluruhan indikator yang telah dianalisis. Dapat diketahui indikator yang memiliki pengaruh paling besar yaitu indikator ketiga. Indikator ketiga memiliki nilai rata-rata sebesar 3,37\%. Dimana indikator ketiga ini adalah mampu memotivasi diri. Indikator ketiga atau memotivasi diri menjadi indikator yang memiliki nilai tertinggi atau yang paling berpengaruh karena motivasi menjadi sangat penting bagi siswa dalam mencapai hasil maksimal dalam proses pembelajaran yang ingin dicapai. Motivasi adalah sebuah dorongan dan semangat dari dalam diri sendiri untuk dapat mencapai atau mendapatkan sesuatu yang diinginkan (Koesmono, 2005), (Ardini, 2010), dan (Murti \& Srimulyani, 2013). 
Untuk variabel hasil belajar. Berdasarkan analisis yang telah dilakukan didapatkan hasil bahwa variabel hasil belajar di SMA Negeri I Kutorejo masuk dalam kategori rendah yaitu sebesar 35,3\%. Hasil belajar merupakan perubahan pengetahuan dan tingkah laku yang didapatkan peserta didik melalui proses pembelajaran (Kresnawati, 2013) dan (Lestari, Fatchan \& Ruja, 2016). Hasil belajar dipengaruhi oleh beberapa faktor, yaitu faktor intern dan ekstern. Faktor intern berasal dari dalam diri siswa, sedangkan faktor ekstern berasal dari luar diri siswa.

Berdasarkan uji hipotesis yang telah dilakukan menggunakan bantuan SPSS 16 menunjukkan bahwa terdapat pengaruh yang signifikan antara kecerdasan emosional dengan hasil belajar Geografi di SMA Negeri I Kutorejo. Hal ini sesuai dengan penelitian (Howe \& Howe, 2016), (Daud, 2012) dan (Brackett, Rivers, \& Salovey, 2011) yang menyatakan terdapat pengaruh yang signifikan antara kecerdasan emosional dengan hasil belajar. Dimana sebelumnya juga menyebutkan bahwa ada dua faktor yang dapat memengaruhi kecerdasan emosional siswa yaitu faktor intern dan faktor ekstern. Siswa yang memiliki kecerdasan emosional yang tinggi akan memiliki peluang lebih besar untuk berhasil dalam proses belajarnya. Kecerdasan emosional dapat dikatakan memiliki peran yang signifikan dalam proses pencapaian belajar siswa (Yani, 2004). Beberapa penelitian sebelumnya juga menyatakan bahwa siswa yang memiliki kecerdasan emosional yang tinggi akan memiliki kemampuan lebih dalam berkonsentrasi, menyelesaikan masalah sehingga hal tersebut dapat membantu dalam memaksimalkan hasil belajarnya (Soltanifar \& Russell, 2012). Perubahan-perubahan peserta didik yang berkaitan dengan tingkah lakunya melalui proses pembelajaran yang dapat menyentuh dimensi-dimensi emosionalnya (Suharini, 2015). Kesimpulannya hasil belajar dapat terwujud dengan baik apabila proses pembelajaran yang dilakukan dapat menyentuh dimensi-dimensi individual atau kelompok. Hal tersebut termasuk juga dalam dimensi emosionalnya.

Beberapa penelitian terdahulu menyebutkan bahwa ternyata hasil belajar lebih banyak dipengaruhi oleh faktor emosi, yaitu (1) daya tahan; (2) kemampuan menjalin kerjasama; (3) motivasi yang tinggi dan dimensi emosional lainnya. Kecerdasan emsional yang tinggi memungkinkan siswa untuk dapat menjalin hubungan yang baik dengan teman-temannya. Selain itu, kecerdasan emosional yang tinggi memungkinkan seseorang untuk dapat menghargai orang lain juga mengenali emosi orang lain. Hal tersebut berdasarkan penelitian terdahulu dapat memberikan hal yang positif terhadap karir hidup seseorang.

Kecerdasan emosional menjadi faktor yang memiliki peran penting dan juga sebagai faktor pelengkap dalam proses pembelajaran (Ellis, 2017). Kecerdasan emosional dan kecerdasan kognitif berada dalam wilayah korteks sedangkan kecerdasan emosional berada dalam wilayah amigdala. Amigdala adalah struktur yang memiliki peran besar dalam ingatan manusia yang menghubungkan pengalaman-pengalaman (Chopra \& Kanji, 2010) Amigdala memberikan pengaruh yang lebih besar terhadap korteks sehingga pembangkitan emosi seseorang dapat mendorong, mendominasi, dan mengontrol pikiran seseorang. Hal ini dikarenakan memiliki pengaruh yang lebih besar daripada korteks (Brackett et al., 2011).

\section{SIMPULAN}

Berdasarkan hasil dan pembahasan yang telah dilakukan dapat disimpulkan bahwa kecerdasan emosional siswa di SMA Negeri I Kutorejo masuk dalam kategori sedang. Sementara itu, hasil belajar Geografi siswa di SMA Negeri I Kutorejo masuk dalam kategori rendah. Berdasarkan analisis yang telah dilakukan peneliti dengan menggunakan bantuan program SPSS diketahui terdapat pengaruh yang signifikan antara kecerdasan emosional dengan hasil belajar Geografi siswa di SMA Negeri I Kutorejo. Hal ini berarti apabila kecerdasan emosional tinggi, maka hasil belajar Geografi di SMA Negeri I Kutorejo juga tinggi.

Berdasarkan penelitian yang telah dilakukan peneliti pada tanggal 1 Februari 2019 saran yang dapat diberikan untuk sekolah, yaitu bagi guru mata pelajaran Geografi agar juga memperhatikan faktor-faktor yang memengaruhi hasil belajar Geografi. Faktor-faktor tersebut yaitu faktor yang berasal dari dalam diri siswa (intern) dan juga faktor yang berasal dari luar diri siswa (ekstern). Berdasarkan hasil, faktor lain yang berasal dari diri siswa yang menjadi variabel dalam penelitian yaitu kecerdasan emosional. Bagi peneliti selanjutnya berdasarkan temuan penelitian masih ada beberapa faktor lain yang dapat memengaruhi hasil belajar agar juga dapat diteliti dan dipertimbangkan.

\section{DAFTAR RUJUKAN}

Brackett, M. A., Rivers, S. E., \& Salovey, P. (2011). Emotional Intelligence: Implications for Personal, Social, Academic, and Workplace Success. Social and Personality Psychology Compass. https://doi.org/10.1111/j.1751-9004.2010.00334.x

Chopra, P. K., \& Kanji, G. K. (2010). Emotional Intelligence: A Catalyst for Inspirational Leadership and Management Excellence. Total Quality Management and Business Excellence. https://doi.org/10.1080/14783363.2010.487704

Daud, F. (2012). Pengaruh Kecerdasan Emosional (EQ) dan Motivasi Belajar terhadap Hasil Belajar Biologi Siswa SMA 3 Negeri Kota Palopo. Jurnal Pendidikan dan Pembelajaran, 19(2), 243-255.

Ellis, R. (2017). Task-Based Language Teaching. In The Routledge Handbook of Instructed Second Language Acquisition. https://doi.org/10.4324/9781315676968

Hanafy, M. S. (2018). Konsep Belajar dan Pembelajaran. Lentera Pendidikan: Jurnal Ilmu Tarbiyah dan Keguruan, 17(1), 6679. https://doi.org/10.24252/lp.2014v17n1a5

Howe, D., \& Howe, D. (2016). What is Emotional Intelligence? In The Emotionally Intelligent Social Worker.

Koesmono, H. T. (2005). Pengaruh Budaya Organisasi terhadap Motivasi dan Kepuasan Kerja serta Kinerja Karyawan pada Sub Sektor Industri Pengolahan Kayu Skala Menengah di Jawa Timur. Jurnal Manajemen dan Kewirausahaan, 7(2), 171188. 
Kresnawati, N. (2013). Korelasi Kualitas Pembelajaran Geografi dan Hasil Belajar terhadap Sikap Peduli Lingkungan Siswa Kelas XII IPS SMAN 1 Ponorogo. Jurnal Pendidikan Humaniora, 1(3), 298-302.

Lestari, D. P., Fatchan, A., \& Ruja, I. N. (2016). Pengaruh Model Pembelajaran Project Based Learning Berbasis Ooutdoor Study terhadap Hasil Belajar Geografi Siswa SMA. Jurnal Pendidikan: Teori, Penelitian, dan Pengembangan, 1(3), 475479.

Lutfriansyah. (2016). Pengaruh Kompetensi, Independensi, dan Motivasi terhadap Kualitas Audit Aparat Inspektorat pada Pemerintah Kota Medan. Jurnal Akuntansi dan Bisnis, 2(1).

Mayer, R. E., \& Mayer, R. E. (2012). A Cognitive Theory of Multimedia Learning. In Multimedia Learning. https://doi.org/10.1017/cbo9781139164603.004

Murti, H., \& Srimulyani, V. A. (2013). Pengaruh Motivasi terhadap Kinerja Pegawai dengan Variabel Pemediasi Kepuasan Kerja pada PDAM Kota Madiun. Jurnal Riset Manajemen dan Akuntansi, 1(1), 10-17.

Retnowati, E., Ayres, P., \& Sweller, J. (2017). Can Collaborative Learning Improve the Effectiveness of Worked Examples in Learning Mathematics? Journal of Educational Psychology. https://doi.org/10.1037/edu0000167

Soltanifar, S., \& Russell, R. (2012). The National Institute for Health and Clinical Excellence (NICE) Guidelines for Caesarean Section, 2011 Update: Implications for the Anesthetist. International Journal of Obstetric Anesthesia. https://doi.org/10.1016/j.ijoa.2012.03.004

Suharini, E. (2015). Studi tentang Kompetensi Pedagogik dan Profesional bagi Guru Geografi di SMA Negeri Kabupaten Pati. Jurnal Geografi, 6(2), 133-145.

Yani, A. (2004). Pemanfaatan Teknologi Informasi dalam Pembelajaran Geografi. Teknologi Informasi. 